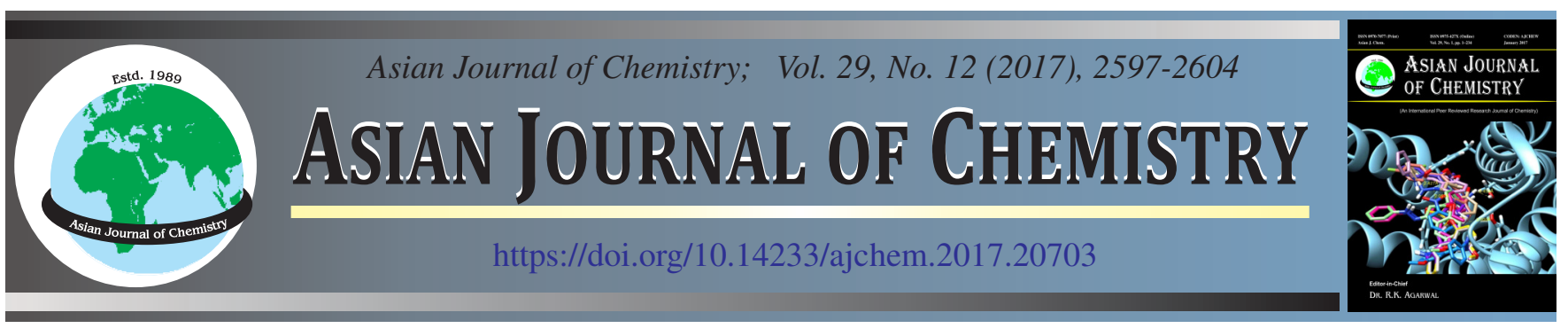

\title{
Study of Intermolecular Interactions in Binary Mixtures of 2-Methylaniline with Isomeric Chlorotoluenes at Various Temperatures
}

\author{
Muvva Raghavendra $^{1}$, A. Venkatesulu ${ }^{2, *}$, M. Gowrisankar ${ }^{3}$ and E. Kalavathi ${ }^{2}$
}

${ }^{1}$ Department of Physics, Rayalaseema University, Kurnool-518 001, India

${ }^{2}$ Department of Physics, Government First Grade College, Hosakote-562 114, India

${ }^{3}$ Department of Chemistry, J.K.C.C. Acharya Nagarjuna University, Guntur-522 006, India

*Corresponding author: E-mail: venkatesuluadavala@gmail.com

Received: 11 April 2017;

Accepted: 6 June 2017;

Published online: 30 October 2017;

AJC-18598

\begin{abstract}
The densities $(\rho)$, ultrasonic speeds $(\mathrm{u})$ and viscosities $(\eta)$ are reported for binary mixtures of 2-methylaniline with isomeric chlorotoluenes namely $o$-chlorotoluene, $m$-chlorotoluene and $p$-chlorotoluene over the entire range of mole fractions at temperatures $303.15,308.15$, 313.15 and $318.15 \mathrm{~K}$ and at atmospheric pressure. The excess properties such as excess molar volume, excess isentropic compressibility and deviation in viscosity are calculated from the density, speed of sound and viscosity and the Redlich-Kister equation, correlates these properties. The excess partial molar properties $\left(\overline{\mathrm{V}}_{\mathrm{m}, 1}^{\mathrm{E}}, \overline{\mathrm{V}}_{\mathrm{m}, 2}^{\mathrm{E}}, \overline{\mathrm{K}}_{\mathrm{s}, \mathrm{m}, 1}^{\mathrm{E}}\right.$ and $\left.\overline{\mathrm{K}}_{\mathrm{s}, \mathrm{m}, 2}^{\mathrm{E}}\right)$ and excess partial molar properties at infinite dilution $\left(\overline{\mathrm{V}}_{\mathrm{m}, 1,1}^{\circ \mathrm{E}}, \overline{\mathrm{V}}_{\mathrm{m}, 2}^{\circ}, \overline{\mathrm{K}}_{\mathrm{s}, \mathrm{m}, 1}^{\circ \mathrm{E}}\right.$ and $\left.\overline{\mathrm{K}}_{\mathrm{s}, \mathrm{m}, 2}^{\circ}\right)$ of components are calculated. The $\mathrm{V}^{\mathrm{E}}$ results are analyzed in the light Prigogine-Flory-Patterson theory. Analyses of each of the three contributions namely, interactional, free volume and $\mathrm{P}^{*}$ to $\mathrm{V}^{\mathrm{E}}$ show that $\mathrm{P}^{*}$ contribution is negative for all systems expect $p$-chlorotoluene, which has positive $\mathrm{P} *$ contribution and interactional contribution is positive for all systems. Further, the free volume effect is negative for all the mixtures. The variations of these parameters with composition and temperature are discussed in terms of intermolecular interactions prevailing in these mixtures.
\end{abstract}

Keywords: Isomeric chlorotoluene, Charge-transfer complex, Partial molar volume, Prigogine-Flory-Patterson theory.

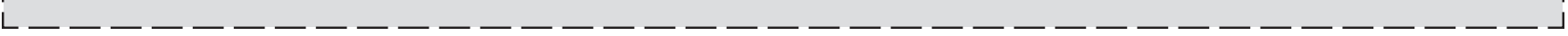

\section{INTRODUCTION}

Thermodynamic properties of mixtures, which contain a blend of organic solvents with isomeric chlorotoluenes, are an important from the technological and theoretical points of view. It is well known that the study of excess thermodynamic properties like excess volume, excess isentropic compressibility is much important to understand the molecular interactions in liquid mixtures and develop and test the solution theories and mathematical models.

Studies of excess thermodynamic functions afford a means of ascertaining the molecular interactions and various other dynamic processes that occur in solutions. The possible interactions that are frequently found in liquids or in blends of liquids are due to hydrogen bonding, loose complexation or charge transfer. The charge transfer complexes are of particular interest as they have diverse applications in chemistry (organic semiconductors), physics and in biology, besides assisting in cellular metabolism in living systems.

The liquids chosen in this present investigation are 2methylaniline and $o-/ m-/ p$-chlorotoluenes. These solvents have industrial importance. 2-Methylaniline is used as an inter- mediate in the production of a number of products such as agricultural chemicals, azo dyes and pigments, bactericide or biocide and pharmaceuticals while chlorotoluenes are used as intermediates in manufacturing pesticide, pharmaceutical formulations and dye industries. A fundamental understanding with regard to intermolecular interactions in the blends of 2methylaniline with chlorotoluenes, is therefore important from the technical and engineering standpoint.

Several researchers investigated density, speed of sound and viscosity of binary mixtures of dimethylformamide with chlorotoluenes [1], tetrahydrofuran with chlorotoluenes [2], dimethylsulfoxide with chlorotoluenes [3] and benzyl alcohol with chlorotoluenes [4]. However, literature survey revealed that no study on excess thermodynamic properties for the systems containing 2-methylaniline with isomeric chlorotoluenes is reported. The present work is to investigate the effect of chloro group and its orientation in toluene molecules which may influence both the sign and magnitude of excess properties when mixed with 2-methylaniline.

The present investigation is a continuation of our earlier research [5] on thermodynamic properties of binary liquid mixtures. In this paper we report measurements of densities, 
speeds of sound and viscosities for three binary systems, 2methylaniline $+o$-chlorotoluene, 2 -methylaniline $+m$-chlorotoluene and 2-methylaniline $+p$-chlorotoluene at $\mathrm{T}=(303.15$ $318.15) \mathrm{K}$ and atmospheric pressure. From the experimental data, various physico-chemical parameters, viz., $\mathrm{V}_{\mathrm{m}}^{\mathrm{E}}, \kappa_{\mathrm{S}}^{\mathrm{E}}, \Delta \eta$ and $\mathrm{G}^{* \mathrm{E}}$ of the mixtures; $\overline{\mathrm{V}}_{\mathrm{m}, 1}$ and $\overline{\mathrm{V}}_{\mathrm{m}, 2}, \overline{\mathrm{K}}_{\mathrm{s}, \mathrm{m}, 1}$ and $\overline{\mathrm{K}}_{\mathrm{s}, \mathrm{m}, 2}, \overline{\mathrm{V}}_{\mathrm{m}, 1}^{\mathrm{E}}$ and $\overline{\mathrm{V}}_{\mathrm{m}, 2}^{\mathrm{E}}$ and $\overline{\mathrm{K}}_{\mathrm{s}, \mathrm{m}, 1}^{\mathrm{E}}$ and $\overline{\mathrm{K}}_{\mathrm{s}, \mathrm{m}, 2}^{\mathrm{E}}$ over whole composition range; $\overline{\mathrm{V}}_{\mathrm{m}, 1}^{\circ}$ and $\overline{\mathrm{V}}_{\mathrm{m}, 2}^{\circ} ; \overline{\mathrm{K}}_{\mathrm{s}, \mathrm{m}, 1}^{\circ}$ and $\overline{\mathrm{K}}_{\mathrm{s}, \mathrm{m}, 2}^{\circ} ; \overline{\mathrm{V}}_{\mathrm{m}, 1}^{\circ \mathrm{E}}$ and $\overline{\mathrm{V}}_{\mathrm{m}, 2}^{\circ \mathrm{E}}$ and $\overline{\mathrm{K}}_{\mathrm{s}, \mathrm{m}, 1}^{\mathrm{oE}}$ and $\overline{\mathrm{K}}_{\mathrm{s}, \mathrm{m}, 2}^{\mathrm{E}}$ of the components in the mixture at infinite dilution, have been calculated. The variations of these properties with composition of the binary mixtures are discussed in terms of molecular interactions between components and structural effects.

\section{EXPERIMENTAL}

Chemicals used in the present study were 2-methylaniline (Sigma Aldrich), $o$-chlorotoluene, $m$-chlorotoluene and $p$ chlorotoluene were purchased from S.D. Fine Chemicals Ltd. Isomeric chlrotoluenes were purified by the method described by Vogel [6]. Each one of the chloro derivatives was washed successively with concentrated sulfuric acid, water, $10 \%$ sodium carbonate and water. Finally, it was dried over calcium chloride and distilled. Before use, the chemicals were stored over $0.4 \mathrm{~nm}$ molecular sieves for about $72 \mathrm{~h}$ to remove water and gas. The purity of liquid samples was checked by gas chromatography. The water contents were determined by Karl-Fischer method. The details of the chemicals and pertaining purification methods are presented in Table- 1 .

All the binary liquid mixtures were prepared by weighing appropriate amount of pure liquids on an Afcoset-ER-120A electric balance using syringe in narrow mouth stoppered bottle. The uncertainty of electronic balance was $\pm 0.05 \mathrm{mg}$ while the accuracy of the mole fraction was $\pm 1 \times 10^{-4}$.

Density and speed of sound of the pure liquids as well as their binary mixtures were measured using an automatic digital vibrating tube density and speed of sound Analyzer (Anton Parr, DSA 5000M). The instrument was first calibrated by comparing the density and speed of sound of the distilled water and dry air with the literature. The operating frequency for speed of sound measurements was $3 \mathrm{MHz}$. The uncertainties associated with the measurements for temperature, density and speed of sound were estimated to be within $\pm 0.01 \mathrm{~K}, \pm 0.5 \times$ $10^{-3} \mathrm{~g} \mathrm{~cm}^{-3}$ and $\pm 0.5 \mathrm{~m} \mathrm{~s}^{-1}$ respectively. The viscosities of pure liquids and their mixtures were determined at atmospheric pressure at $\mathrm{T}=(303.15-318.15) \mathrm{K}$ by using an Ubbelohde viscometer, which was calibrated with benzene, carbon tetrachloride, acetonitrile and doubly distilled water. The details of the methods and measurement techniques were described elsewhere [7]. An electronic digital stopwatch with an uncertainty of $\pm 0.01 \mathrm{~s}$ was used for flow time measurements. The experimental uncertainty of viscosity was estimated as $\pm 1.13 \%$ and the uncertainty of temperature $\pm 0.1 \mathrm{~K}$. The purity of all these solvents were compared with the measured densities, speeds of sound and viscosities of the pure liquids with the literature [8-14] and are enlisted in Table-3.

\section{RESULTS AND DISCUSSION}

The experimental densities and viscosities for all the binary systems at various compositions are used to calculate the excess thermodynamic functions using following equations:

$$
\begin{gathered}
\mathrm{V}^{\mathrm{E}}\left(\mathrm{m}^{3} \mathrm{~mol}^{-1}\right)=\left[\mathrm{x}_{1} \mathrm{M}_{1}+\mathrm{x}_{2} \mathrm{M}_{2}\right] / \rho-\left[\mathrm{x}_{1} \mathrm{M}_{1} / \rho_{1}+\mathrm{x}_{2} \mathrm{M}_{2} / \rho_{2}\right] \\
\Delta \eta(\mathrm{mPa} \mathrm{s})=\eta-\left(\mathrm{x}_{1} \eta_{1}+\mathrm{x}_{2} \eta_{2}\right) \\
\mathrm{G}^{* \mathrm{E}}\left(\mathrm{J} \mathrm{mol}{ }^{-1}\right)=\mathrm{RT}\left[\ln \eta \mathrm{V}-\left(\mathrm{x}_{1} \ln \eta_{1} \mathrm{~V}_{1}+\mathrm{x}_{2} \ln \eta_{2} \mathrm{~V}_{2}\right)\right]
\end{gathered}
$$

where $\rho, \eta$ and $V$ are density, viscosity and molar volume of the binary mixture. $x_{1}, M_{1}, \rho_{1}, \eta_{1}, V_{1}$ and $x_{2}, M_{2}, \rho_{2}, \eta_{2}, V_{2}$ are the mole fraction, molar mass, density, viscosity and molar volume of pure components 1 and 2 respectively. $\mathrm{R}$ is the gas constant and $\mathrm{T}$ is the absolute temperature.

The experimental data is used to compute isentropic compressibility $\left(\kappa_{\mathrm{s}}\right)$ by using the following relation:

\begin{tabular}{|c|c|c|c|c|c|c|}
\hline \multicolumn{7}{|c|}{$\begin{array}{c}\text { TABLE-1 } \\
\text { PROVENANCE AND PURITY OF MATERIALS USED IN THIS WORK }\end{array}$} \\
\hline Chemical name & $\begin{array}{l}\text { CAS } \\
\text { number }\end{array}$ & Source & $\begin{array}{l}* * \text { Water content } \\
\text { mass fraction }\end{array}$ & $\begin{array}{l}\text { Purification } \\
\text { method }\end{array}$ & $\begin{array}{l}* \text { Analysis } \\
\text { method }\end{array}$ & $\begin{array}{l}\text { Purity in mass } \\
\text { fraction }\end{array}$ \\
\hline 2-Methylaniline & $95-53-4$ & Sigma Aldrich India & 0.0004 & No purification & GC & 0.995 \\
\hline$p$-Chlorotoluene & $106-43-4$ & S.D. Fine Chemicals, India & 0.0004 & Distillation & GC & 0.995 \\
\hline$m$-Chlorotoluene & $108-41-8$ & S.D. Fine Chemicals, India & 0.0004 & Distillation & GC & 0.995 \\
\hline$o$-Chlorotoluene & $95-49-8$ & S.D. Fine Chemicals, India & 0.0004 & Distillation & GC & 0.995 \\
\hline
\end{tabular}

$$
\kappa_{\mathrm{s}}=\left(\mathrm{u}^{2} \rho\right)^{-1}
$$

TABLE-2

COMPARISON OF EXPERIMENTAL AND LITERATURE VALUES OF DENSITY ( $\rho$ ), VISCOSITY ( $\eta$ ) AND SPEED OF SOUND (u) DATA OF PURE COMPONENTS AT T $=303.15 \mathrm{~K}$ AND $0.1 \mathrm{MPa}$ PRESSURE

\begin{tabular}{lcc|cc|ccc}
\hline \multirow{2}{*}{ Pure components } & \multicolumn{2}{c|}{ Density $\left(\mathrm{g} \mathrm{cm}^{-3}\right)$} & \multicolumn{2}{c|}{ Viscosity $(\mathrm{mPa} \mathrm{s})$} & \multicolumn{2}{c}{ Speed of sound $\left(\mathrm{m} \mathrm{s}^{-1}\right)$} & \multirow{2}{*}{$\mathrm{C}_{\mathrm{p}}\left(\mathrm{J} \mathrm{K}^{-1} \mathrm{~mol}^{-1}\right)$} \\
\cline { 2 - 7 } & Experimental & Literature & Experimental & Literature & Experimental & Literature & \\
\hline 2-Methylaniline & 0.99019 & $0.9901[9]$ & 3.258 & $3.31^{*}[10]$ & 1578.5 & $1579.0[9]$ & $218.43[8]$ \\
$o$-Chlorotoluene & 1.07285 & $.07283[11]$ & 0.886 & $0.884[14]$ & 1285.0 & $1284.0[14]$ & $179.59[12]$ \\
$m$-Chlorotoluene & 1.06283 & $.06281[11]$ & 0.743 & $0.746[11]$ & 1281.0 & $1280.0[14]$ & $173.07[12]$ \\
$p$-Chlorotoluene & 1.05953 & $.05951[13]$ & 0.782 & $0.782[11]$ & 1273.0 & $1271.0[14]$ & $172.74[12]$ \\
\hline
\end{tabular}

*298.15 K; The standard uncertainties are $\mathrm{u}(\rho)=0.5 \times 10^{-3} \mathrm{~g} \mathrm{~cm}^{-3}, \mathrm{u}(\mathrm{u})= \pm 0.5 \mathrm{~m} \mathrm{~s}^{-1}, \mathrm{u}(\eta)=1.13 \%, \mathrm{u}(\mathrm{T})=0.01 \mathrm{~K}$ for density, $\mathrm{u}(\mathrm{T})=0.01 \mathrm{~K}$ for speed of sound, $u(T)=0.1 \mathrm{~K}$ for viscosity and $\mathrm{u}(\mathrm{p})=1 \mathrm{kPa}$. 
TABLE-3

DENSITY $(\rho)$, VISCOSITY $(\eta)$ AND SPEED OF SOUND (u) OF BINARY LIQUID MIXTURES OF 2-METHYLANILINE WITH para-CHLOROTOLUENE, meta-CHLOROTOLUENE and ortho-CHLOROTOLUENE AT T $=(303.15$ to 318.15$) \mathrm{K}$ AND 0.1MPa PRESSURE

\begin{tabular}{|c|c|c|c|c|c|c|c|c|c|c|c|c|}
\hline \multirow{2}{*}{$\mathrm{x}_{1}$} & \multicolumn{4}{|c|}{ Density $\left(\mathrm{g} \mathrm{cm}^{-3}\right)$} & \multicolumn{4}{|c|}{ Viscosity (mPa s) } & \multicolumn{4}{|c|}{ Speed of sound $\left(\mathrm{m} \mathrm{s}^{-1}\right)$} \\
\hline & 303.15 & 308.15 & 313.15 & 318.15 & 303.15 & 308.15 & 313.15 & 318.15 & 303.15 & 308.15 & 313.15 & 318.15 \\
\hline \multicolumn{13}{|c|}{ 2-Methylaniline (1) + para-Chlorotoluene (2) } \\
\hline 0.0000 & 1.05953 & 1.05537 & 1.05118 & 1.04721 & 0.782 & 0.731 & 0.681 & 0.632 & 1273.0 & 1256.7 & 1241.4 & 1227.0 \\
\hline 0.0857 & 1.05419 & 1.05004 & 1.04585 & 1.04188 & 1.045 & 0.963 & 0.879 & 0.800 & 1295.0 & 1279.3 & 1264.5 & 1250.6 \\
\hline 0.1851 & 1.04787 & 1.04372 & 1.03952 & 1.03554 & 1.338 & 1.221 & 1.101 & 0.988 & 1321.7 & 1306.0 & 1291.2 & 1277.1 \\
\hline 0.2804 & 1.04170 & 1.03754 & 1.03333 & 1.02933 & 1.608 & 1.458 & 1.305 & 1.159 & 1348.3 & 1332.3 & 1317.1 & 1302.3 \\
\hline 0.3927 & 1.03423 & 1.03007 & 1.02585 & 1.02183 & 1.914 & 1.725 & 1.534 & 1.351 & 1380.8 & 1364.2 & 1348.4 & 1332.8 \\
\hline 0.5011 & 1.02684 & 1.02267 & 1.01843 & 1.01440 & 2.196 & 1.969 & 1.740 & 1.524 & 1413.2 & 1396.2 & 1379.9 & 1363.7 \\
\hline 0.6126 & 1.01902 & 1.01484 & 1.01059 & 1.00655 & 2.471 & 2.206 & 1.938 & 1.691 & 1447.7 & 1430.5 & 1413.8 & 1397.3 \\
\hline 0.7222 & 1.01112 & 1.00694 & 1.00268 & 0.99863 & 2.723 & 2.422 & 2.117 & 1.841 & 1482.8 & 1465.3 & 1448.5 & 1432.0 \\
\hline 0.8307 & 1.00309 & 0.99892 & 0.99465 & 0.99058 & 2.952 & 2.618 & 2.280 & 1.975 & 1518.8 & 1501.0 & 1483.8 & 1467.1 \\
\hline 0.9203 & 0.99633 & 0.99214 & 0.98786 & 0.98378 & 3.123 & 2.763 & 2.404 & 2.074 & 1549.8 & 1531.1 & 1513.1 & 1495.3 \\
\hline 1.0000 & 0.99019 & 0.98599 & 0.98169 & 0.97759 & 3.258 & 2.878 & 2.508 & 2.153 & 1578.5 & 1558.2 & 1538.5 & 1518.5 \\
\hline \multicolumn{13}{|c|}{ 2-Methylaniline (1) + meta-Chlorotoluene (2) } \\
\hline 0.0000 & 1.06283 & 1.05805 & 1.05331 & 1.04856 & 0.743 & 0.702 & 0.663 & 0.624 & 1281.0 & 1264.9 & 1249.7 & 1234.5 \\
\hline 0.0901 & 1.05694 & 1.05222 & 1.04753 & 1.04285 & 1.015 & 0.940 & 0.864 & 0.793 & 1304.7 & 1289.2 & 1274.5 & 1259.7 \\
\hline 0.1948 & 1.04995 & 1.04530 & 1.04065 & 1.03603 & 1.324 & 1.212 & 1.098 & 0.988 & 1332.9 & 1317.4 & 1302.6 & 1287.6 \\
\hline 0.2901 & 1.04344 & 1.03884 & 1.03424 & 1.02969 & 1.598 & 1.452 & 1.305 & 1.161 & 1359.2 & 1343.3 & 1328.0 & 1312.7 \\
\hline 0.4023 & 1.03561 & 1.03106 & 1.02651 & 1.02202 & 1.908 & 1.722 & 1.535 & 1.356 & 1391.2 & 1374.8 & 1358.9 & 1342.8 \\
\hline 0.5121 & 1.02773 & 1.02325 & 1.01874 & 1.01433 & 2.198 & 1.973 & 1.744 & 1.530 & 1423.6 & 1406.6 & 1390.2 & 1373.3 \\
\hline 0.6225 & 1.01961 & 1.01519 & 1.01073 & 1.00639 & 2.472 & 2.208 & 1.943 & 1.696 & 1457.3 & 1440.0 & 1423.0 & 1406.1 \\
\hline 0.7312 & 1.01139 & 1.00705 & 1.00265 & 0.99837 & 2.724 & 2.423 & 2.118 & 1.842 & 1491.5 & 1473.7 & 1456.6 & 1439.7 \\
\hline 0.8484 & 1.00230 & 0.99803 & 0.99368 & 0.98949 & 2.973 & 2.634 & 2.293 & 1.985 & 1529.2 & 1511.1 & 1493.7 & 1476.9 \\
\hline 0.9517 & 0.99410 & 0.98989 & 0.98557 & 0.98144 & 3.172 & 2.804 & 2.441 & 2.101 & 1562.8 & 1543.9 & 1525.2 & 1506.5 \\
\hline 1.0000 & 0.99019 & 0.98599 & 0.98169 & 0.97759 & 3.258 & 2.878 & 2.508 & 2.153 & 1578.5 & 1558.2 & 1538.5 & 1518.5 \\
\hline \multicolumn{13}{|c|}{ 2-Methylaniline (1) + ortho-Chlorotoluene (2) } \\
\hline 0.0000 & 1.07285 & 1.06815 & 1.06348 & 1.05896 & 0.886 & 0.804 & 0.723 & 0.642 & 1285.0 & 1265.7 & 1246.1 & 1227.0 \\
\hline 0.0997 & 1.06537 & 1.06074 & 1.05611 & 1.05165 & 1.165 & 1.048 & 0.931 & 0.819 & 1312.5 & 1294.0 & 1274.9 & 1256.6 \\
\hline 0.2049 & 1.05729 & 1.05271 & 1.04813 & 1.04370 & 1.459 & 1.308 & 1.158 & 1.012 & 1341.2 & 1322.7 & 1303.6 & 1285.4 \\
\hline 0.3179 & 1.04842 & 1.04390 & 1.03935 & 1.03497 & 1.767 & 1.582 & 1.397 & 1.215 & 1372.7 & 1353.8 & 1334.7 & 1315.6 \\
\hline 0.4219 & 1.04007 & 1.03560 & 1.03109 & 1.02676 & 2.039 & 1.821 & 1.602 & 1.392 & 1402.3 & 1383.3 & 1363.8 & 1344.5 \\
\hline 0.5297 & 1.03123 & 1.02681 & 1.02234 & 1.01805 & 2.304 & 2.054 & 1.799 & 1.562 & 1434.0 & 1414.8 & 1395.2 & 1376.1 \\
\hline 0.6307 & 1.02276 & 1.01839 & 1.01396 & 1.00970 & 2.537 & 2.255 & 1.971 & 1.706 & 1464.8 & 1445.5 & 1426.0 & 1407.1 \\
\hline 0.7449 & 1.01296 & 1.00864 & 1.00427 & 1.00007 & 2.780 & 2.464 & 2.144 & 1.854 & 1500.5 & 1480.9 & 1462.0 & 1443.5 \\
\hline 0.8526 & 1.00349 & 0.99924 & 0.99491 & 0.99076 & 2.991 & 2.645 & 2.297 & 1.982 & 1534.5 & 1515.0 & 1496.7 & 1478.6 \\
\hline 0.9535 & 0.99445 & 0.99024 & 0.98593 & 0.98182 & 3.176 & 2.805 & 2.440 & 2.099 & 1565.2 & 1545.9 & 1526.9 & 1507.7 \\
\hline 1.0000 & 0.99019 & 0.98599 & 0.98169 & 0.97759 & 3.258 & 2.878 & 2.508 & 2.153 & 1578.5 & 1558.2 & 1538.5 & 1518.5 \\
\hline
\end{tabular}

The method used for calculating $\kappa_{\mathrm{s}}^{\mathrm{E}}$ (Benson-Kiyohara approach) is outlined previously [15]. $\mathrm{V}^{\mathrm{E}}, \kappa_{\mathrm{s}}^{\mathrm{E}}$ and $\Delta \eta$ values are fitted to Redlich-Kister [16] polynomial equation:

$$
\mathrm{Y}^{\mathrm{E}}=\mathrm{x}_{1} \mathrm{x}_{2} \sum_{\mathrm{i}=0}^{\mathrm{j}} \mathrm{A}_{\mathrm{i}}\left(1-2 \mathrm{x}_{1}\right)^{\mathrm{i}}
$$

where $\mathrm{Y}^{\mathrm{E}}$ is the $\mathrm{V}^{\mathrm{E}}, \kappa_{\mathrm{s}}^{\mathrm{E}}$ and $\Delta \eta$. Values of the coefficients $\mathrm{A}_{\mathrm{i}}$ have been determined by using the method of least-squares. The standard deviations $\sigma\left(\mathrm{Y}^{\mathrm{E}}\right)$ have been calculated by using the formula:

$$
\sigma\left(\mathrm{Y}^{\mathrm{E}}\right)=\left[\Sigma\left(\mathrm{Y}_{\text {exp }}^{\mathrm{E}} \mathrm{Y}_{\text {cal }}^{\mathrm{E}}\right)^{2} /(\mathrm{m}-\mathrm{n})\right]^{1 / 2}
$$

where $m$ is the total number of experimental points and $n$ is the number of parameters. The coefficients $\left(\mathrm{A}_{\mathrm{i}}\right)$ and corresponding standard deviation values (s) are presented in Table- 4 .

The experimental values of density $(\rho)$, viscosity $(\eta)$ and speed of sound (u) of the binary mixtures of 2-methylaniline with isomeric chlorotoluenes over the entire composition range, expressed in mole fraction of 2-methylaniline at different temperatures was presented in Table-2. The values of excess molar volumes $\left(\mathrm{V}^{\mathrm{E}}\right)$, excess isentropic compressibilities $\left(\kappa_{\mathrm{s}}^{\mathrm{E}}\right)$, viscosity deviation $(\eta)$ and excess Gibbs energy of activa-tion of viscous flow $\left(\mathrm{G}^{* \mathrm{E}}\right)$ as functions of mole fraction $\left(\mathrm{x}_{1}\right)$ of 2methylaniline were provided in Table-3. The plots of $\mathrm{V}^{\mathrm{E}}, \kappa_{\mathrm{s}}^{\mathrm{E}}$, $\Delta \eta$ and $\mathrm{G}^{* \mathrm{E}}$ against mole fraction $\left(\mathrm{x}_{1}\right)$ at $303.15 \mathrm{~K}$ were represented in Figs. 1-4, respectively.

The observed values of excess functions depend upon several factors, which are of physical and/or chemical nature [17]. The physical contributions involve dispersion forces and non-specific (weak) interactions, which contribute to negative $\Delta \eta, \mathrm{G}^{* \mathrm{E}}$ or positive $\mathrm{V}^{\mathrm{E}}$ and $\kappa_{\mathrm{s}}^{\mathrm{E}}$ values. Chemical contributions involve breaking up of the associates present (if any), which result in positive $\mathrm{V}^{\mathrm{E}}$ and $\kappa_{\mathrm{s}}^{\mathrm{E}}$ or negative $\Delta \eta$ and $\mathrm{G}^{* \mathrm{E}}$ values. It also involves specific interactions such as formation of hydrogen bonds, charge-transfer complexes or strong dipole interactions between component molecules that lead to positive $\Delta \eta$ and $\mathrm{G}^{* \mathrm{E}}$ or negative $\mathrm{V}^{\mathrm{E}}$ and $\kappa_{\mathrm{s}}^{\mathrm{E}}$ values.

The difference in $\mathrm{V}^{\mathrm{E}}$ and $\kappa_{\mathrm{s}}^{\mathrm{E}}$ values observed between $o$-chlorotoluene, $m$-chlorotoluene and $p$-chlorotoluene is probably because of difference in their shapes, which lead to 
TABLE-4

EXCESS MOLAR VOLUME $\left(V^{\mathrm{E}}\right)$, EXCESS ISENTROPIC COMPRESSIBILITY $\left(\kappa_{\mathrm{s}}^{\mathrm{E}}\right)$, DEVIATION IN VISCOSITY $(\Delta \eta)$ AND EXCESS

GIBBS FREE ENERGY OF ACTIVATION OF VISCOUS FLOW $\left(\mathrm{G}^{* \mathrm{E}}\right)$ OF LIQUID MIXTURES OF 2-METHYLANILINE WITH para-

CHLOROTOLUENE, meta-CHLOROTOLUENE and ortho-CHLOROTOLUENE at T = (303.15 to 318.15) K AND 0.1 MPa PRESSURE

\begin{tabular}{|c|c|c|c|c|c|c|c|c|c|c|c|c|c|c|c|}
\hline \multirow{2}{*}{$\mathrm{X}_{1}$} & \multicolumn{6}{|c|}{$\mathrm{V}^{\mathrm{E}}\left(\mathrm{cm}^{3} \mathrm{~mol}^{-1}\right)$} & \multicolumn{4}{|c|}{$\Delta \eta(\mathrm{mPa} \mathrm{s})$} & \multicolumn{5}{|c|}{$\kappa_{\mathrm{s}}^{\mathrm{E}}\left(\mathrm{TPa}^{-1}\right)$} \\
\hline & 303.15 & \multicolumn{2}{|c|}{308.15} & \multicolumn{2}{|c|}{313.15} & 318.15 & 303.15 & 308.15 & 313.15 & 318.15 & \multicolumn{2}{|c|}{303.15} & 308.15 & 313.15 & 318.15 \\
\hline \multicolumn{16}{|c|}{ 2-Methylaniline (1) + para-Chlorotoluene (2) } \\
\hline 0.0000 & 0.0000 & \multicolumn{2}{|c|}{0.0000} & \multicolumn{2}{|c|}{0.0000} & 0.0000 & 0.000 & 0.000 & 0.000 & 0.000 & \multicolumn{2}{|c|}{0.000} & 0.000 & 0.000 & 0.000 \\
\hline 0.0857 & -0.0097 & \multicolumn{2}{|c|}{-0.0111} & -0 . & 129 & -0.0145 & 0.051 & 0.048 & 0.041 & 0.038 & -2.9 & 49 & -3.807 & -4.665 & -5.681 \\
\hline 0.1851 & -0.0195 & -0.02 & & -0 . & 237 & -0.0256 & 0.098 & 0.092 & 0.082 & 0.074 & -5.9 & 10 & -7.156 & -8.370 & -9.661 \\
\hline 0.2804 & -0.0288 & -0.03 & & -0 . & 323 & -0.0343 & 0.132 & 0.125 & 0.112 & 0.101 & -8.1 & 35 & 9.419 & -10.63 & -11.75 \\
\hline 0.3927 & -0.0354 & -0.03 & & -0 . & 392 & -0.0408 & 0.160 & 0.151 & 0.135 & 0.122 & -9.8 & 32 & -11.02 & -12.11 & -12.94 \\
\hline 0.5011 & -0.0378 & -0.03 & & -0 . & 412 & -0.0428 & 0.173 & 0.162 & 0.144 & 0.130 & -10 . & 42 & -11.55 & -12.58 & -13.34 \\
\hline 0.6126 & -0.0356 & -0.03 & & -0 . & 391 & -0.0407 & 0.172 & 0.160 & 0.138 & 0.127 & -9.8 & 86 & -11.06 & -12.16 & -13.16 \\
\hline 0.7222 & -0.0288 & -0.03 & & -0 . & 327 & -0.0345 & 0.153 & 0.141 & 0.117 & 0.110 & -8.2 & 66 & -9.523 & -10.76 & -12.14 \\
\hline 0.8307 & -0.0185 & -0.02 & & -0 . & 224 & -0.0246 & 0.113 & 0.103 & 0.081 & 0.079 & -5.6 & 70 & -6.855 & -8.064 & -9.624 \\
\hline 0.9203 & -0.0093 & -0.01 & & -0 . & 122 & -0.0139 & 0.062 & 0.056 & 0.042 & 0.042 & -2.8 & 79 & -3.676 & -4.507 & -5.659 \\
\hline 1.0000 & 0.0000 & 0.00 & & & 000 & 0.0000 & 0.000 & 0.000 & 0.000 & 0.000 & 0.0 & & 0.000 & 0.000 & 0.000 \\
\hline & & & & & & 2-Me & lanilin & $+m e t$ & Chlorotolu & ne (2) & & & & & \\
\hline 0.0901 & -0.0116 & -0.01 & & -0 . & 152 & -0.0166 & 0.045 & 0.042 & 0.035 & 0.031 & -3.7 & 05 & -4.600 & -5.571 & -6.491 \\
\hline 0.1948 & -0.0233 & -0.02 & & -0 . & 276 & -0.0289 & 0.091 & 0.086 & 0.075 & 0.066 & -6.9 & 92 & 8.351 & -9.543 & -10.79 \\
\hline 0.2901 & -0.0315 & -0.03 & & -0 . & 359 & -0.0381 & 0.125 & 0.118 & 0.107 & 0.093 & -9.1 & 30 & -10.46 & -11.61 & -12.83 \\
\hline 0.4023 & -0.0381 & -0.04 & & -0 . & 423 & -0.0437 & 0.154 & 0.145 & 0.130 & 0.116 & -10 . & 68 & -11.96 & -13.00 & -13.98 \\
\hline 0.5121 & -0.0396 & -0.04 & & -0 . & 436 & -0.0456 & 0.167 & 0.156 & 0.137 & 0.123 & -11 . & 23 & -12.33 & -13.30 & -14.14 \\
\hline 0.6225 & -0.0377 & -0.03 & & -0 . & 417 & -0.0433 & 0.163 & 0.152 & 0.131 & 0.120 & -10 . & 77 & -11.97 & -12.84 & -13.93 \\
\hline 0.7312 & -0.0307 & -0.03 & & -0 . & 362 & -0.0370 & 0.142 & 0.130 & 0.106 & 0.100 & -9.2 & 64 & -10.30 & -11.43 & -12.87 \\
\hline 0.8484 & -0.0194 & -0.02 & & -0 . & 241 & -0.0258 & 0.096 & 0.086 & 0.065 & 0.063 & -6.2 & 98 & -7.340 & -8.483 & -10.23 \\
\hline 0.9517 & -0.0074 & -0.00 & & -0 . & 104 & -0.0109 & 0.036 & 0.031 & 0.022 & 0.022 & -2.3 & 42 & -3.077 & -3.559 & -4.283 \\
\hline 1.0000 & 0.0000 & 0.00 & & $0 .($ & 00 & 0.0000 & 0.000 & 0.000 & 0.000 & 0.000 & 0.0 & & 0.000 & 0.000 & 0.000 \\
\hline & & & & & & 2-Me & niline & + orth & lorotc & e (2) & & & & & \\
\hline 0.0000 & 0.0000 & 0.0 & & $0 .($ & 000 & 0.0000 & 0.000 & 0.000 & 0.000 & 0.000 & 0.0 & & 0.000 & 0.000 & 0.000 \\
\hline 0.0997 & -0.0157 & -0.01 & & -0 . & 195 & -0.0212 & 0.042 & 0.037 & 0.030 & 0.027 & -4.9 & 33 & -6.024 & -6.892 & -8.080 \\
\hline 0.2049 & -0.0266 & -0.02 & & -0 . & 320 & -0.0330 & 0.087 & 0.079 & 0.069 & 0.060 & -8.2 & 69 & -9.534 & -10.68 & -12.25 \\
\hline 0.3179 & -0.0355 & -0.03 & & -0 . & 406 & -0.0422 & 0.127 & 0.118 & 0.106 & 0.093 & -10 . & & -11.84 & -13.01 & -14.03 \\
\hline 0.6307 & -0.0395 & -0.04 & & -0 . & 447 & -0.0456 & 0.155 & 0.143 & 0.122 & 0.111 & -11 . & 65 & -12.72 & -13.65 & -14.98 \\
\hline 0.7449 & -0.0321 & -0.03 & & -0 . & 381 & -0.0398 & 0.127 & 0.115 & 0.092 & 0.086 & -10 . & 11 & -10.95 & -12.16 & -13.65 \\
\hline 0.8526 & -0.0214 & -0.02 & & -0 . & 277 & -0.0290 & 0.083 & 0.073 & 0.052 & 0.052 & -7.3 & 55 & 8.155 & -9.466 & -11.08 \\
\hline 0.9535 & -0.0093 & -0.01 & & -0 . & 125 & -0.0133 & 0.028 & 0.024 & 0.015 & 0.016 & -2.8 & 79 & -3.586 & -4.143 & -4.849 \\
\hline 1.0000 & 0.0000 & 0.00 & & & 00 & 0.0000 & 0.000 & 0.000 & 0.000 & 0.000 & 0.0 & & 0.000 & 0.000 & 0.000 \\
\hline $\mathrm{X}_{1}$ & & $\begin{array}{l}\text { Methyla } \\
\text {-Chlorot } \\
\mathrm{G}^{* \mathrm{E}}(\mathrm{J}\end{array}$ & nol & $\begin{array}{l}\text { (1) } \\
(2)\end{array}$ & & $\mathrm{X}_{1}$ & & $\begin{array}{r}\text { Methyla } \\
\text {-Chloro } \\
\mathrm{G}^{* \mathrm{E}}(\mathrm{J} \\
\end{array}$ & $\begin{array}{l}\text { iline }(1)+ \\
\text { oluene }(2) \\
\left.\mathrm{mol}^{-1}\right)\end{array}$ & & $\mathrm{x}_{1}$ & & $\begin{array}{r}\text { 2-Methyla } \\
o-C h l o r o \\
\mathrm{G}^{* \mathrm{E}}\end{array}$ & $\begin{array}{l}\text { niline (1) } \\
\text { oluene (2 } \\
\left.\mathrm{mol}^{-1}\right)\end{array}$ & \\
\hline & 303.15 & 308.15 & 31 & .15 & 318. & & 303.15 & 308.15 & 313.15 & 318.15 & & 303.15 & 308.15 & 313.15 & 318.15 \\
\hline 0.0000 & 0.000 & 0.000 & & 00 & 0.0 & 0.0000 & 0.000 & 0.000 & 0.000 & 0.000 & 0.0000 & 0.000 & 0.000 & 0.000 & 0.000 \\
\hline 0.0857 & 4.174 & 4.001 & 3. & 88 & 3.4 & 0.0901 & 4.456 & 4.181 & 3.725 & 3.351 & 0.0997 & 3.581 & 3.487 & 3.322 & 3.226 \\
\hline 0.1851 & 6.807 & 6.567 & & 59 & 5.7 & 0.1948 & 7.231 & 6.869 & 6.313 & 5.722 & 0.2049 & 5.778 & 5.706 & 5.560 & 5.418 \\
\hline 0.2804 & 8.008 & 7.758 & & 48 & 6.88 & 0.2901 & 8.404 & 8.040 & 7.503 & 6.849 & 0.3179 & 6.891 & 6.867 & 6.771 & 6.628 \\
\hline 0.3927 & 8.356 & 8.121 & & 34 & 7.28 & 0.4023 & 8.696 & 8.364 & 7.840 & 7.270 & 0.4219 & 7.081 & 7.036 & 6.976 & 6.896 \\
\hline 0.5011 & 7.924 & 7.717 & & & $6.9^{\circ}$ & 0.5121 & 8.171 & 7.880 & 7.374 & 6.878 & 0.5297 & 6.636 & 6.578 & 6.505 & 6.489 \\
\hline 0.6126 & 6.895 & 6.723 & & 76 & 6.10 & 0.6225 & 7.035 & 6.791 & 6.365 & 5.993 & 0.6307 & 5.753 & 5.705 & 5.623 & 5.607 \\
\hline 0.7222 & 5.420 & 5.287 & & 72 & 4.8 & 0.7312 & 5.449 & 5.255 & 4.867 & 4.638 & 0.7449 & 4.326 & 4.295 & 4.138 & 4.166 \\
\hline 0.8307 & 3.573 & 3.485 & & 36 & $3.1^{\prime}$ & 0.8484 & 3.311 & 3.185 & 2.891 & 2.787 & 0.8526 & 2.656 & 2.626 & 2.462 & 2.387 \\
\hline 0.9203 & 1.783 & 1.739 & & 93 & 1.58 & 0.9517 & 1.116 & 1.069 & 0.954 & 0.924 & 0.9535 & 0.875 & 0.856 & 0.778 & 0.745 \\
\hline 1.0000 & 0.000 & 0.000 & 0. & & 0.0 & 1.0000 & 0.000 & 0.000 & 0.000 & 0.000 & 1.0000 & 0.000 & 0.000 & 0.000 & 0.000 \\
\hline
\end{tabular}

different alignments in the liquid mixtures. Further, the chlorine atom in $p$-chlorotoluene, which is at $4^{\text {th }}$ position in benzene ring causes the least steric hindrance to 2-methylanilne molecules and thus the electron donor-acceptor interactions in it are lowering than of ortho and meta chlorotoluenes.

Results show that $\mathrm{V}^{\mathrm{E}}$ and $\kappa_{\mathrm{s}}^{\mathrm{E}}$ values are negative for all binary mixtures over the whole composition range at temperature from 303.15 to $318.15 \mathrm{~K}$. This suggests the presence of specific interaction may be attributed to the formation of charge-transfer complexes between unlike molecules with 2-methylaniline acting as electron pair donor and benzene ring of aromatic hydrocarbons as electron pair acceptor.

The values of $\mathrm{V}^{\mathrm{E}}$ for the binary mixtures of 2-methylaniline with chlorotoluenes fall in the following order: 


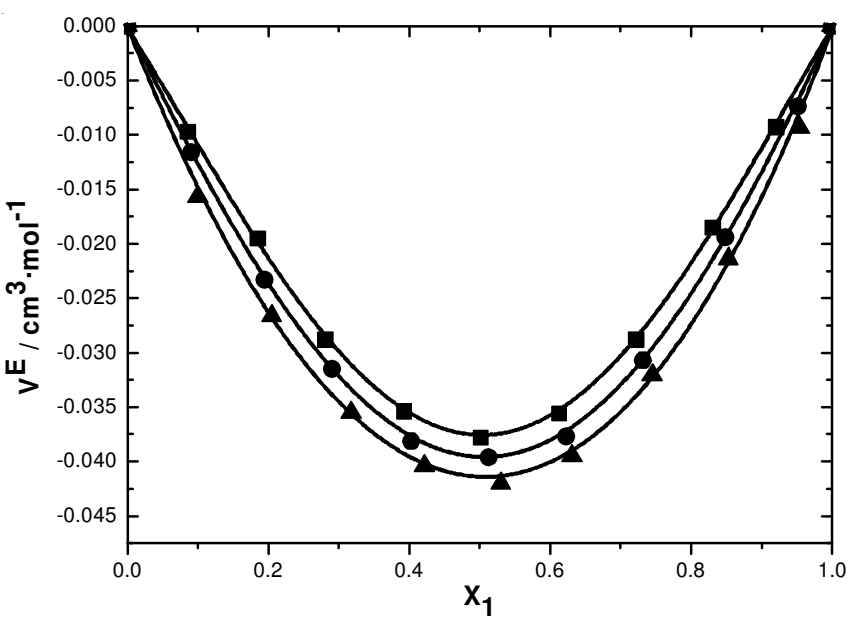

Fig. 1

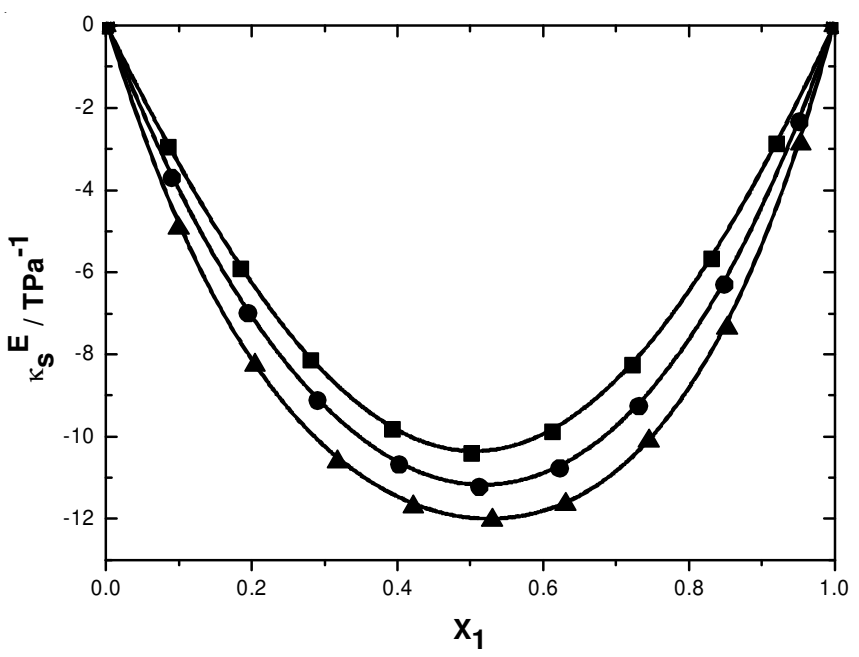

Fig. 2

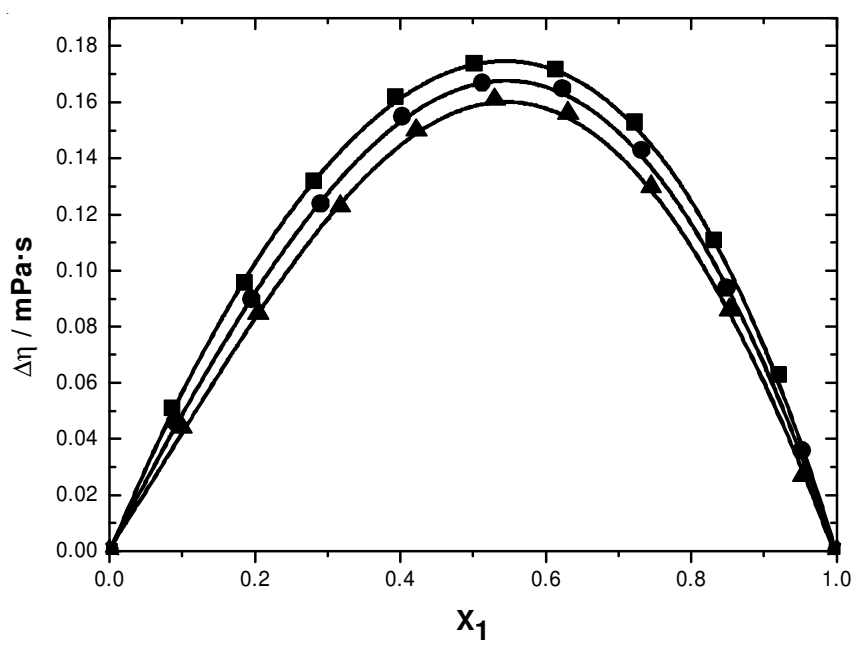

Fig. 3

\section{$o$-Chlorotoluene $>m$-Chlorotoluene $>p$-Chlorotoluene}

The values of $\mathrm{V}^{\mathrm{E}}$ are decreased (become more negative) as the temperature increased for all the binary systems. Increase in temperature promotes the kinetic energy and therefore breaking up of associates of 2-methylaniline molecules releasing more and more free dipoles in the liquid mixture which

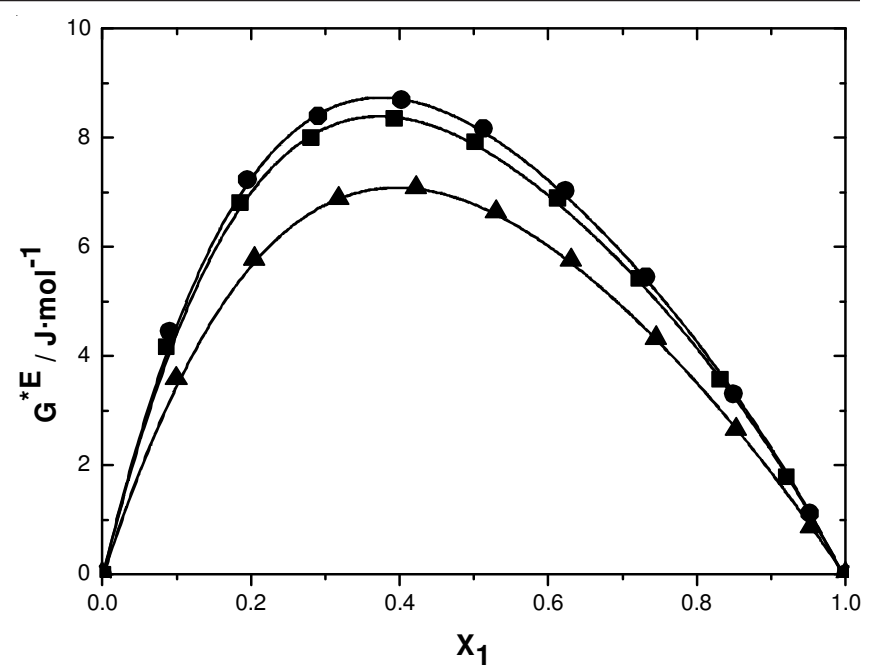

Fig. 4

results in interacting with isomeric chlorotoluenes and forming greater number of charge transfer complexes. As a result, the values of $\mathrm{V}^{\mathrm{E}}$ become more negative with increasing temperature.

In the present investigation, the negative $\kappa_{\mathrm{s}}^{\mathrm{E}}$ values indicate that the dipole-dipole interactions between the components of the mixtures, resulting the formation of electron donoracceptor complexes [18]. Thus, the formation of complexes between the components of the mixtures leads to a decrease in the intermolecular distances and increase in sound velocities, thereby decreasing the isentropic compressibilities of the mixtures [19].

The values of $\kappa_{\mathrm{s}}^{\mathrm{E}}$ for the binary mixtures of 2-methylaniline with isomeric chlorotoluenes is the following order:

\section{$o$-Chlorotoluene $>m$-Chlorotoluene $>p$-Chlorotoluene}

The $\pi$-electron density of the derivatives of benzene ring depends upon the group which is attached to it. The hetero molecular interaction between component molecules depends upon the net electron density in the ring. Further, these interactions seem to depend upon relative orientation of the two groups in the ring. As the separation between the two groups' increases, the intermolecular interaction is expected to decrease. The intermolecular interaction in ortho isomer causes a large strain in the ring, causing an opposite pole at ortho side of the ring and thus giving a dipolar character, than meta and para derivatives. Thus, the intermolecular interactions in ortho position become stronger than the meta and para isomers due to stronger polar character. Hence, above order is justified.

The values of deviation in viscosity and excess Gibbs energy of activation of viscous flow are dependent on the position of the $-\mathrm{Cl}$ group in the toluene molecule, indicating a different extent of molecular interactions in chlorotoluene molecules. The values of $\eta$ and $G^{*}$ are positive for all the binary mixtures over the entire composition range all investigated temperatures. The positive $\eta$ and $\mathrm{G}^{* \mathrm{E}}$ values indicate the formation of molecular complexes in solution [20].

Partial molar properties: The interpretations of excess partial molar properties $\left(\overline{\mathrm{V}}_{\mathrm{m}, 1}^{\mathrm{E}}, \overline{\mathrm{V}}_{\mathrm{m}, 2}^{\mathrm{E}}, \overline{\mathrm{K}}_{\mathrm{s}, \mathrm{m}, 1}^{\mathrm{E}}\right.$ and $\left.\overline{\mathrm{K}}_{\mathrm{s}, \mathrm{m}, 2}^{\mathrm{E}}\right)$ and excess partial molar properties at infinite dilution $\left(\overline{\mathrm{V}}_{\mathrm{m}, 1}^{\mathrm{oE}}, \overline{\mathrm{V}}_{\mathrm{m}, 2}^{\circ \mathrm{E}}\right.$, $\overline{\mathrm{K}}_{\mathrm{s}, \mathrm{m}, 1}^{\mathrm{oE}}$ and $\overline{\mathrm{K}}_{\mathrm{s}, \mathrm{m}, 2}^{\mathrm{eE}}$ ) of components 2 have previously been described [8]. 
COEFFICIENTS OF REDLICH-KISTER EQUATION AND STANDARD DEVIATION $(\sigma)$ VALUES FOR LIQUID MIXTURES OF 2-METHYLANILINE WITH ISOMERIC CHLOROTOLUENES AT T $=(303.15-318.15) \mathrm{K}$

\begin{tabular}{|c|c|c|c|c|c|c|c|c|c|}
\hline \multirow{2}{*}{ Binary mixtures } & \multirow{2}{*}{ Functions } & $\mathrm{A}_{1}$ & $\mathrm{~A}_{2}$ & $\mathrm{~A}_{3}$ & $\sigma$ & $\mathrm{A}_{1}$ & $\mathrm{~A}_{2}$ & $\mathrm{~A}_{3}$ & $\sigma$ \\
\hline & & \multicolumn{4}{|c|}{$303.15 \mathrm{~K}$} & \multicolumn{4}{|c|}{$308.15 \mathrm{~K}$} \\
\hline \multirow{3}{*}{$\begin{array}{l}\text { 2-Methylaniline + } \\
p \text {-chlorotoluene }\end{array}$} & $\mathrm{V}^{\mathrm{E}}\left(\mathrm{cm}^{3} \mathrm{~mol}^{-1}\right)$ & -0.150 & -0.002 & 0.039 & 0.001 & -0.157 & -0.003 & 0.019 & 0.001 \\
\hline & $\Delta \eta(\mathrm{mPa} \mathrm{s})$ & 0.693 & 0.120 & 0.076 & 0.002 & 0.649 & 0.094 & 0.054 & 0.001 \\
\hline & $\kappa_{\mathrm{S}}^{\mathrm{E}}\left(\mathrm{TPa}^{-1}\right)$ & -41.66 & -1.023 & 4.623 & 0.001 & -46.19 & -0.864 & -4.533 & 0.001 \\
\hline \multirow{2}{*}{$\begin{array}{l}\text { 2-Methylaniline + } \\
m \text {-chlorotoluene }\end{array}$} & $\mathrm{V}^{\mathrm{E}}\left(\mathrm{cm}^{3} \mathrm{~mol}^{-1}\right)$ & -0.159 & -0.008 & 0.012 & 0.001 & -0.164 & -0.009 & -0.019 & 0.001 \\
\hline & $\Delta \eta(\mathrm{mPa} s)$ & 0.664 & 0.129 & -0.008 & 0.001 & 0.623 & 0.098 & -0.042 & 0.001 \\
\hline \multirow{3}{*}{$\begin{array}{l}\text { 2-Methylaniline + } \\
o \text {-chlorotoluene }\end{array}$} & $\mathrm{V}^{\mathrm{E}}\left(\mathrm{cm}^{3} \mathrm{~mol}^{-1}\right)$ & -0.162 & -0.009 & -0.032 & 0.001 & -0.171 & -0.013 & -0.063 & 0.001 \\
\hline & $\Delta \eta(\mathrm{mPa} s)$ & 0.644 & 0.112 & -0.129 & 0.001 & 0.602 & 0.093 & -0.179 & 0.001 \\
\hline & $\kappa_{\mathrm{S}}^{\mathrm{E}}\left(\mathrm{TPa}^{-1}\right)$ & -47.94 & -3.975 & -15.89 & 0.063 & -51.35 & -3.138 & -28.87 & 0.031 \\
\hline & & \multicolumn{4}{|c|}{$313.15 \mathrm{~K}$} & \multicolumn{4}{|c|}{$318.15 \mathrm{~K}$} \\
\hline \multirow{3}{*}{$\begin{array}{l}\text { 2-Methylaniline + } \\
p \text {-chlorotoluene }\end{array}$} & $\mathrm{V}^{\mathrm{E}}\left(\mathrm{cm}^{3} \mathrm{~mol}^{-1}\right)$ & -0.163 & -0.002 & 0.001 & 0.001 & -0.168 & -0.003 & -0.022 & 0.001 \\
\hline & $\Delta \eta(\mathrm{mPa} \mathrm{s})$ & 0.576 & 0.029 & -0.039 & 0.001 & 0.521 & 0.055 & 0.017 & 0.001 \\
\hline & $\kappa_{\mathrm{S}}^{\mathrm{E}}\left(\mathrm{TPa}^{-1}\right)$ & -50.17 & -0.952 & -14.63 & 0.001 & -53.13 & -2.401 & -30.82 & 0.001 \\
\hline \multirow{2}{*}{$\begin{array}{l}\text { 2-Methylaniline + } \\
m \text {-chlorotoluene }\end{array}$} & $\Delta \eta(\mathrm{mPa} s)$ & 0.553 & 0.036 & -0.146 & 0.001 & 0.498 & 0.062 & -0.095 & 0.001 \\
\hline & $\kappa_{\mathrm{S}}^{\mathrm{E}}\left(\mathrm{TPa}^{-1}\right)$ & -52.67 & -2.365 & -26.27 & 0.155 & -56.58 & -4.262 & -39.93 & 0.177 \\
\hline \multirow{3}{*}{$\begin{array}{c}\text { 2-Methylaniline }+ \\
o \text {-chlorotoluene }\end{array}$} & $\mathrm{V}^{\mathrm{E}}\left(\mathrm{cm}^{3} \mathrm{~mol}^{-1}\right)$ & -0.180 & -0.019 & -0.085 & 0.001 & -0.185 & -0.017 & -0.101 & 0.001 \\
\hline & $\Delta \eta(\mathrm{mPa} \mathrm{s})$ & 0.530 & 0.026 & -0.268 & 0.001 & 0.476 & 0.057 & -0.206 & 0.001 \\
\hline & $\kappa_{\mathrm{S}}^{\mathrm{E}}\left(\mathrm{TPa}^{-1}\right)$ & -55.14 & -3.832 & -39.30 & 0.314 & -59.31 & -4.414 & -53.97 & 0.273 \\
\hline
\end{tabular}

\section{TABLE-6}

VALUES $\overline{\mathrm{V}}_{\mathrm{m}, 1}^{\mathrm{E}}(\mathrm{A}), \overline{\mathrm{V}}_{\mathrm{m}, 2}^{\mathrm{E}}(\mathrm{B}), \overline{\mathrm{K}}_{\mathrm{s}, \mathrm{m}, 1}^{\mathrm{E}}(\mathrm{C}) \overline{\mathrm{K}}_{\mathrm{s}, \mathrm{m}, 2}^{\mathrm{E}}$ (D) OF LIQUID MIXTURES OF

2-METHYLANILINE WITH ISOMERIC CHLOROTOLUENES AT T = (303.15-318.15) K

\begin{tabular}{|c|c|c|c|c|c|c|c|c|c|c|c|c|c|c|c|c|}
\hline \multirow[b]{2}{*}{$\mathrm{X}_{1}$} & \multicolumn{2}{|c|}{$303.15 \mathrm{~K}$} & \multicolumn{2}{|c|}{$308.15 \mathrm{~K}$} & \multicolumn{2}{|c|}{$313.15 \mathrm{~K}$} & \multicolumn{2}{|c|}{$318.15 \mathrm{~K}$} & \multicolumn{2}{|c|}{$303.15 \mathrm{~K}$} & \multicolumn{2}{|c|}{$308.15 \mathrm{~K}$} & \multicolumn{2}{|c|}{$313.15 \mathrm{~K}$} & \multicolumn{2}{|c|}{$318.15 \mathrm{~K}$} \\
\hline & A & B & A & B & A & B & A & B & $\mathrm{C}$ & $\mathrm{D}$ & $\mathrm{C}$ & $\mathrm{D}$ & $\mathrm{C}$ & $\mathrm{D}$ & $\mathrm{C}$ & $\mathrm{D}$ \\
\hline & \multicolumn{16}{|c|}{ 2-Methylaniline (1) + para-Chlorotoluene (2) } \\
\hline 0.0000 & -0.114 & 0.000 & 140 & 0.000 & 4 & 0.000 & -0.193 & 0.000 & -41.63 & 0.000 & -56.95 & 00 & -73.16 & .000 & -96.72 & 0.000 \\
\hline 0.0857 & -0.109 & -0.001 & -0.124 & -0.001 & .137 & -0.001 & -0.152 & 0.002 & -37.88 & -0.182 & -45.63 & -0.496 & -53.47 & -0.843 & -63.53 & -1.401 \\
\hline 0.1851 & -0.096 & -0.002 & -0.102 & -0.004 & 108 & -0.006 & -0.115 & -0.008 & -32.12 & -1.104 & -35.16 & -2.120 & -37.84 & -3.237 & -39.70 & -5.017 \\
\hline 0.2804 & -0.079 & -0.008 & -0.082 & -0.010 & -0.084 & -0.013 & -0.086 & -0.016 & -25.93 & -2.996 & -27.19 & -4.528 & -27.98 & -6.193 & -27.00 & -8.786 \\
\hline 0.3927 & -0.057 & -0.020 & -0.058 & -0.023 & -0.060 & -0.025 & -0.061 & -0.028 & -18.64 & -6.709 & -19.70 & -8.321 & -20.36 & -10.01 & -19.56 & -12.46 \\
\hline 0.6126 & -0.020 & -0.061 & -0.022 & -0.062 & -0.024 & -0.061 & -0.026 & -0.061 & -7.005 & -18.50 & 940 & -19.23 & -10.84 & -19.70 & -12.89 & -19.25 \\
\hline 0.7222 & -0.009 & -0.085 & -0.010 & -0.085 & -0.012 & -0.085 & -0.014 & -0.084 & -3.269 & -25.97 & -5.002 & -27.17 & -6.79 & -27.93 & -9.08 & -27.09 \\
\hline 0.8307 & -0.002 & -0.103 & -0.003 & -0.108 & -0.005 & -0.112 & -0.006 & -0.115 & -1.047 & -33.62 & -2.048 & -37.51 & -3.103 & -40.94 & 4.561 & -43.24 \\
\hline 0.9203 & -0.001 & -0.111 & -0.001 & -0.124 & -0.001 & -0.137 & -0.001 & -0.149 & -0.194 & -39.53 & -0.495 & -48.52 & -0.817 & -57.32 & -1.276 & -66.96 \\
\hline \multirow[t]{2}{*}{1.0000} & 0.000 & -0.109 & 0.000 & -0.134 & 0.000 & -0.161 & 0.000 & -0.188 & 0.000 & -43.97 & 0.000 & -60.72 & 0.000 & -77.82 & 0.000 & -99.38 \\
\hline & \multicolumn{16}{|c|}{ 2-Methylaniline (1) + meta-Chlorotoluene (2) } \\
\hline 00 & 154 & 0.000 & 93 & 0.000 & 224 & 0.000 & -0.239 & 0.000 & -57.22 & 0.000 & -75.63 & 0.000 & 0.74 & 00 & .0 & 0.000 \\
\hline & & & & & & & & & & & & & -37.99 & & 40.43 & -6.627 \\
\hline 0.2901 & -0.079 & -0.013 & -0.081 & -0.018 & -0.084 & -0.021 & -0.087 & -0.022 & -25.45 & -5.006 & -25.90 & -6.958 & -26.61 & -8.485 & -26.57 & -10.95 \\
\hline 0.4023 & -0.055 & -0.026 & -0.056 & -0.030 & -0.057 & -0.034 & -0.059 & -0.035 & -17.98 & -8.948 & -18.51 & -10.82 & -19.42 & -12.22 & -19.34 & -14.66 \\
\hline & & & & & & & & & -12.25 & & & & -15.38 & & & -17.10 \\
\hline 0.6225 & -0.020 & -0.064 & -0.022 & -0.063 & -0.024 & -0.065 & -0.026 & -0.065 & -7.687 & -19.76 & -9.765 & -20.04 & -11.93 & -20.18 & -13.83 & -20.54 \\
\hline 0.7312 & -0.010 & -0.086 & -0.012 & -0.085 & -0.013 & -0.087 & -0.015 & -0.088 & -4.165 & -27.16 & -6.108 & -27.80 & -8.021 & -28.53 & -9.962 & -28.91 \\
\hline & 003 & & 04 & -0.116 & & -0.1 & -0 & & -1.450 & -37.43 & -2.472 & -41.78 & -3.447 & -46.25 & -4.514 & -50.19 \\
\hline 0.9517 & -0.001 & -0.130 & -0.001 & -0.153 & 001 & -0.168 & -0.001 & -0.1 & -0.161 & -49.19 & -0.310 & -61.88 & -0.449 & -74.32 & -0.608 & -86.97 \\
\hline \multirow[t]{2}{*}{1.0000} & 0.000 & -0.138 & 0.000 & -0.174 & 0.000 & -0.197 & 0.000 & -0.217 & 0.000 & -55.77 & 0.000 & -74.72 & 0.000 & -93.01 & 0.000 & -112.3 \\
\hline & \multicolumn{16}{|c|}{ 2-Methylaniline (1) + ortho-Chlorotoluene (2) } \\
\hline 0.0000 & -0.204 & 0.000 & 247 & 0.000 & 285 & 0.000 & -0.304 & 0.000 & -74.63 & 0.000 & -92.32 & 0.000 & -109.5 & 0.000 & -131.9 & 0.000 \\
\hline 0.0997 & -0.149 & -0.003 & -0.170 & -0.004 & -0.189 & -0.005 & -0.198 & -0.006 & -50.17 & -1.215 & -56.84 & -1.739 & -64.05 & -2.218 & -72.80 & -2.867 \\
\hline 0.2049 & -0.106 & -0.011 & -0.114 & -0.014 & -0.122 & -0.017 & -0.126 & -0.019 & -33.55 & -4.130 & -34.86 & -5.563 & -36.92 & -6.921 & -38.82 & -8.736 \\
\hline 0.3179 & -0.073 & -0.022 & -0.075 & -0.027 & -0.077 & -0.031 & -0.079 & -0.033 & -22.73 & -7.890 & -22.66 & -9.758 & -23.01 & -11.67 & -22.86 & -14.15 \\
\hline 0.4219 & -0.051 & -0.033 & -0.052 & -0.038 & -0.053 & -0.042 & -0.054 & -0.044 & -16.64 & -11.43 & -17.25 & -12.87 & -17.82 & -14.64 & -18.23 & -16.76 \\
\hline 0.5297 & -0.034 & -0.047 & -0.036 & -0.049 & -0.036 & -0.053 & -0.038 & -0.053 & -12.31 & -15.35 & -14.06 & -15.75 & -15.39 & -16.82 & -17.04 & -17.80 \\
\hline 0.8526 & -0.004 & -0.117 & -0.005 & -0.124 & -0.006 & -0.130 & -0.007 & -0.136 & -2.236 & -40.68 & -3.343 & -45.16 & -4.189 & -49.28 & -5.376 & -54.14 \\
\hline 0.9535 & -0.001 & -0.159 & -0.001 & -0.183 & -0.001 & -0.200 & -0.001 & -0.216 & -0.274 & -59.55 & -0.430 & -73.41 & -0.550 & -84.70 & -0.719 & -99.62 \\
\hline 1.0000 & 0.000 & -0.185 & 0.000 & -0.221 & 0.000 & -0.246 & 0.000 & -0.269 & 0.000 & -71.35 & 0.000 & -92.01 & 0.000 & -108.5 & 0.000 & -130.8 \\
\hline
\end{tabular}


A close perusal of Table-5 indicates that the values of $\bar{V}_{\mathrm{m}, 1}^{\mathrm{E}}$, $\overline{\mathrm{V}}_{\mathrm{m}, 2}^{\mathrm{E}}, \overline{\mathrm{K}}_{\mathrm{s}, \mathrm{m}, 1}^{\mathrm{E}}$ and $\overline{\mathrm{K}}_{\mathrm{s}, \mathrm{m}, 2}^{\mathrm{E}}$ are negative for all the binary mixtures over the whole composition range. The negative values indicate that the formation of hydrogen bond complexes $(-\mathrm{NH} \ldots . . \pi)$ between unlike molecules in the mixtures.

From the Table-6, it can be seen that the values of $\overline{\mathrm{V}}_{\mathrm{m}, 1}^{\mathrm{oE}}$, $\overline{\mathrm{V}}_{\mathrm{m}, 2}^{\mathrm{oE}}, \overline{\mathrm{K}}_{\mathrm{s}, \mathrm{m}, 1}^{\mathrm{oE}}$ and $\overline{\mathrm{K}}_{\mathrm{s}, \mathrm{m}, 2}^{\mathrm{oE}}$ are negative for all the binary mixtures over the whole composition range. The negative values may be attributed to the formation of complex through dipole-dipole or electron donor-acceptor interactions between unlike molecules in the mixtures [21,22].

Prigogine-Flory-Patterson theory: The Prigogine-FloryPatterson theory considers excess thermodynamic properties of binary mixtures to be the sum of different contributions [23-25]. The excess molar volume can be expressed as an interactional term which is proportional to the interaction parameter, $\mathrm{c}_{12}$, a free volume contribution which arises from the dependence of the reduced volume upon the reduced temperature as a result of the differences between the degrees of thermal expansion of the components and an internal pressures and of the reduced volumes of the components:

$$
\begin{gathered}
\frac{\mathrm{V}^{\mathrm{E}}}{\mathrm{x}_{1} \mathrm{~V}_{1}^{*}+\mathrm{x}_{2} \mathrm{~V}_{2}^{*}}=\frac{\left(\tilde{\mathrm{V}}^{1 / 3}-1\right) \tilde{\mathrm{V}}^{2 / 3}}{\left[(4 / 3) \tilde{\mathrm{V}}^{-1 / 3}-1\right]} \Psi_{1} \theta_{2}\left(\frac{\chi_{12}}{\mathrm{P}_{1}^{*}}\right) \text { int. } \\
\text { contribution })-\frac{\left(\mathrm{V}_{1}-\mathrm{V}_{2}\right)^{2}\left[(14 / 9) \tilde{\mathrm{V}}^{-1 / 3}-1\right] \Psi_{1} \Psi_{2}}{\left.\left[(4 / 3) \tilde{\mathrm{V}}^{-1 / 3}-1\right)\right] \tilde{\mathrm{V}}}(\mathrm{fv} . \\
\text { contribution })+\frac{\left(\tilde{\mathrm{V}}_{1}-\tilde{\mathrm{V}}_{2}\right)\left(\mathrm{P}_{1}^{*}-\mathrm{P}_{2}^{*}\right)}{\mathrm{P}_{1}^{*} \Psi_{2}+\mathrm{P}_{2}^{*} \Psi_{2}}\left(\mathrm{P}^{*} \text { contribution }\right)
\end{gathered}
$$

The reduced volume of pure component $\tilde{V}_{i}$ was calculated from the isobaric thermal expansively by equation:

$$
\tilde{\mathrm{V}}_{\mathrm{i}}=\left(\frac{1+\left(\frac{4}{3}\right) \alpha_{\mathrm{i}} \mathrm{T}}{1+\alpha_{\mathrm{i}} \mathrm{T}}\right)
$$

The $\tilde{\mathrm{V}}$ of mixture is approximated in eqn. 8 by

$$
\tilde{\mathrm{V}}=\Psi_{1} \tilde{\mathrm{V}}_{1}+\Psi_{2} \tilde{\mathrm{V}}_{2}
$$

The molecular contact energy fraction of components is given by

$$
\Psi_{1}=1-\Psi_{2}=\frac{\phi_{1} \mathrm{P}_{1}^{*}}{\phi_{1} \mathrm{P}_{1}^{*}+\phi_{2} \mathrm{P}_{2}^{*}}
$$

The characteristic volume is $\mathrm{V}_{\mathrm{i}}^{*}=\mathrm{V}_{\mathrm{i}}^{*} / \tilde{\mathrm{V}}_{\mathrm{i}}$ and the characteristic pressure is given by

$$
\mathrm{P}_{\mathrm{i}}^{*}=\frac{\mathrm{TV}_{\mathrm{i}}^{2} \alpha_{\mathrm{i}}}{\kappa_{\mathrm{Ti}}}
$$

where $\kappa_{\mathrm{Ti}}$ is the isothermal compressibility of pure component i.

The hard-core volume fractions of the components 1 and $2\left(\phi_{1}\right.$ and $\left.\phi_{2}\right)$ are defined by

$$
\phi_{1}=1-\phi_{2}=\frac{\mathrm{x}_{1} \mathrm{~V}_{1}^{*}}{\mathrm{x}_{1} \mathrm{~V}_{1}^{*}+\mathrm{x}_{2} \mathrm{~V}_{2}^{*}}
$$

The $\kappa_{\mathrm{T}}$ values were calculated from the following expression:

$$
\kappa_{\mathrm{T}}=\kappa_{\mathrm{S}}+\frac{\mathrm{TV} \alpha^{2}}{\mathrm{C}_{\mathrm{P}}}
$$

The $\chi_{12}$ parameter required for the calculation of $\mathrm{V}^{\mathrm{E}} \mathrm{using}$ Prigogine-Flory-Patterson theory were derived by fitting the $\mathrm{V}^{\mathrm{E}}$ expression to the experimental equimolar value of $\mathrm{V}^{\mathrm{E}}$ for each system investigated. The calculated equimolar value of the three contributions together with the $\chi_{12}$ parameter for each system was listed in Table-7. An analysis of each of the three

\begin{tabular}{|c|c|c|c|c|c|c|c|c|c|c|c|c|}
\hline \multirow{3}{*}{$\mathrm{T}(\mathrm{K})$} & \multicolumn{11}{|c|}{$\begin{array}{l}\text { VALUES } \overline{\mathrm{V}}_{\mathrm{m}, 1}^{\mathrm{o}}, \mathrm{V}_{\mathrm{m}, 1}^{*}, \overline{\mathrm{V}}_{\mathrm{m}, 1}^{\mathrm{oE}}, \overline{\mathrm{V}}_{\mathrm{m}, 2}^{\mathrm{o}}, \mathrm{V}_{\mathrm{m}, 2}^{*}, \overline{\mathrm{V}}_{\mathrm{m}, 2}^{\mathrm{oE}}, \overline{\mathrm{K}}_{\mathrm{s}, \mathrm{m}, 1}^{\mathrm{o}}, \mathrm{K}_{\mathrm{s}, \mathrm{m}, 1}^{*}, \overline{\mathrm{K}}_{\mathrm{s}, \mathrm{m}, 2}^{\mathrm{o}}, \mathrm{K}_{\mathrm{s}, \mathrm{m}, 2}^{*} \text { AND } \overline{\mathrm{K}}_{\mathrm{s}, \mathrm{m}, 2}^{\mathrm{o}} \text { OF THE COMPONENTS } \\
\text { FOR 2-METHYLANILINE + para-CHLOROTOLUENE , 2-METHYLANILINE + meta-CHLOROTOLUENE } \\
\text { AND 2-METHYLANILINE + ortho-CHLOROTOLUENE BINARY MIXTURES AT T = }(303.15-318.15) \mathrm{K}\end{array}$} & \multirow[b]{2}{*}{$\overline{\mathrm{K}}_{\mathrm{s}, \mathrm{m}, 2}^{\mathrm{oE}}$} \\
\hline & $\overline{\mathrm{V}}_{\mathrm{m}, 1}^{\mathrm{o}}$ & $\mathrm{V}_{\mathrm{m}, 1}^{*}$ & $\overline{\mathrm{V}}_{\mathrm{m}, 1}^{\mathrm{oE}}$ & $\overline{\mathrm{V}}_{\mathrm{m}, 2}^{\mathrm{o}}$ & $\mathrm{V}_{\mathrm{m}, 2}^{*}$ & $\overline{\mathrm{V}_{\mathrm{m}, 2}^{\mathrm{oE}}}$ & $\overline{\mathrm{K}}_{\mathrm{s}, \mathrm{m}, 1}^{\mathrm{o}}$ & $\mathrm{K}_{\mathrm{s}, \mathrm{m}, 1}^{*}$ & $\overline{\mathrm{K}}_{\mathrm{s}, \mathrm{m}, 1}^{\mathrm{oE}}$ & $\overline{\mathrm{K}}_{\mathrm{s}, \mathrm{m}, 2}^{\mathrm{oE}}$ & $\mathrm{K}_{\mathrm{s}, \mathrm{m}, 2}^{*}$ & \\
\hline & \multicolumn{6}{|c|}{$\mathrm{cm}^{3} \mathrm{~mol}^{-1}$} & \multicolumn{6}{|c|}{$\mathrm{TPa}^{-1}$} \\
\hline & \multicolumn{12}{|c|}{ 2-Methylaniline (1) + para-Chlorotoluene (2) } \\
\hline 308.15 & 108.55 & 108.69 & -0.140 & 119.81 & 119.95 & -0.134 & -52.41 & 4.540 & -56.95 & -53.52 & 7.197 & -60.72 \\
\hline 313.15 & 109.00 & 109.17 & -0.164 & 120.27 & 120.43 & -0.161 & -68.46 & 4.698 & -73.16 & -70.38 & 7.434 & -77.82 \\
\hline \multirow[t]{2}{*}{318.15} & 109.43 & 109.63 & -0.193 & 120.70 & 120.88 & -0.188 & -91.85 & 4.863 & -96.72 & -91.72 & 7.667 & -99.38 \\
\hline & \multicolumn{12}{|c|}{ 2-Methylaniline (1) + meta-Chlorotoluene (2) } \\
\hline 303.15 & 108.08 & 108.23 & -0.154 & 118.97 & 119.11 & -0.138 & -52.84 & 4.387 & -57.22 & -48.94 & 6.829 & -55.77 \\
\hline 308.15 & 108.50 & 108.69 & -0.193 & 119.47 & 119.64 & -0.174 & -71.09 & 4.540 & -75.63 & -67.65 & 7.068 & -74.72 \\
\hline 313.15 & 108.94 & 109.17 & -0.224 & 119.99 & 120.18 & -0.197 & -86.04 & 4.698 & -90.74 & -85.71 & 7.306 & -93.01 \\
\hline 318.15 & \multicolumn{12}{|c|}{ 2-Methylaniline (1) + ortho-Chlorotoluene (2) } \\
\hline 303.15 & 108.03 & 108.23 & -0.204 & 117.81 & 117.99 & -0.185 & -70.24 & 4.387 & -74.63 & -64.69 & 6.661 & -71.35 \\
\hline 308.15 & 108.45 & 108.69 & -0.247 & 118.29 & 118.51 & -0.221 & -87.78 & 4.540 & -92.32 & -85.08 & 6.926 & -92.01 \\
\hline 313.15 & 108.88 & 109.17 & -0.285 & 118.79 & 119.03 & -0.247 & -104.8 & 4.698 & -109.5 & -101.3 & 7.208 & -108.5 \\
\hline 318.15 & 109.32 & 109.63 & -0.304 & 119.27 & 119.54 & -0.269 & -127.0 & 4.863 & -131.9 & -123.3 & 7.498 & -130.8 \\
\hline
\end{tabular}
contributions to $\mathrm{V}^{\mathrm{E}}$ showed that the interactional contribution was positive for all systems, the free volume contribution was negative for all the mixtures and $\mathrm{P}^{*}$ contribution was negative for all the mixtures except $p$-chlorotoluene, which had a positive internal pressure term. It is clear from Table-7 that the dominant role is played by the free volume contribution and this is the main parameter for deciding the sign and magnitude of excess volumes for 2-methylaniline + isomeric chlorotoluenes. 
TABLE-8

PRIGOGINE-FLORY-PATTERSON (PFP) INTERACTION PARAMETER, $\chi_{12}$ AND CALCULATED VALUES OF THE THREE CONTRIBUTIONS FROM THE PFP THEORY WITH EXPERIMENTAL EXCESS MOLAR VOLUMES AT $x_{1}=0.5$ AT $303.15 \mathrm{~K}$

\begin{tabular}{|c|c|c|c|c|c|c|c|}
\hline \multirow{2}{*}{ Binary mixtures } & \multirow{2}{*}{$\chi_{12}\left(10^{6}\right)$} & \multicolumn{3}{|c|}{ Calculated contributions } & \multicolumn{2}{|c|}{$\mathrm{V}_{\mathrm{m}}^{\mathrm{E}}(\mathrm{x}=0.5)$} & \multirow{2}{*}{$\delta\left(\mathrm{cm}^{3} \mathrm{~mol}^{-1}\right)$} \\
\hline & & Interactional $\left(10^{-8}\right)$ & Free volume & $\mathrm{P} *$ effect & EXP & PFP & \\
\hline 2-Methoxyaniline $+o$-Chlorotoluene & 1.764 & 1.123 & -0.0030 & -0.0590 & -0.0422 & -0.0416 & -0.0006 \\
\hline 2-Methoxyaniline $+m$-Chlorotoluene & 5.965 & 1.148 & -0.0089 & -0.0995 & -0.0400 & -0.0398 & -0.0002 \\
\hline 2-Methoxyaniline $+p$-Chlorotoluene & -7.034 & 1.139 & -0.0008 & 0.0429 & -0.0380 & -0.0378 & -0.0002 \\
\hline
\end{tabular}

\section{Conclusion}

This paper reports experimental data of densities, speeds of sound and viscosities of binary blends of 2-methylaniline with isomeric chlorotoluenes ( $o$-chlorotoluene, $m$-chlorotoluene, $p$-chlorotoluene $)$ at $\mathrm{T}=(303.15-318.15) \mathrm{K}$ with $5 \mathrm{~K}$ interval. From the experimental data, various physico-chemical parameters, viz., $\mathrm{V}^{\mathrm{E}}, \kappa_{\mathrm{S}}^{\mathrm{E}}$ and $\Delta \eta$ of the mixtures, the excess partial molar properties $\left(\mathrm{V}_{\mathrm{m}, 1}^{\mathrm{E}}, \overline{\mathrm{V}}_{\mathrm{m}, 2}^{\mathrm{E}}, \overline{\mathrm{K}}_{\mathrm{s}, \mathrm{m}, 1}^{\mathrm{E}}\right.$ and $\left.\overline{\mathrm{K}}_{\mathrm{s}, \mathrm{m}, 2}^{\mathrm{E}}\right)$ and excess partial molar properties at infinite dilution $\left(\overline{\mathrm{V}}_{\mathrm{m}, 1}^{\circ \mathrm{E}}, \overline{\mathrm{V}}_{\mathrm{m}, 2}^{\circ \mathrm{E}}, \overline{\mathrm{K}}_{\mathrm{s}, \mathrm{m}, 1}^{\circ \mathrm{E}}\right.$ and $\overline{\mathrm{K}}_{\mathrm{s}, \mathrm{m}, 2}^{\mathrm{oE}}$ ) of components have been calculated. The results were analyzed in terms of intermolecular interaction through dipole-dipole and donor-acceptor interactions between 2-methylaniline and isomeric chlorotoluene molecules. Moreover, the $\mathrm{V}^{\mathrm{E}}$ values have been analyzed with Prigogine-Flory-Patterson theory and shown that the free volume contribution is the main factor for negative values of excess molar quantities.

\section{REFERENCES}

1. V. Syamala, D.R. Sekhar, K.S. Kumar and P. Venkateswarlu, Chinese J. Chem., 25, 32 (2007); https://doi.org/10.1002/cjoc. 200790013.

2. P.M. Reddy, K.S. kumar and P. Venkatesu, Fluid Phase Equilib., 310, 74 (2011); https://doi.org/10.1016/j.fluid.2011.07.018

3. V. Syamala, K.S. Kumar and P. Venkateswarlu, J. Chem. Thermodyn., 38, 1553 (2006);

https://doi.org/10.1016/j.jct.2006.04.005.

4. L. Venkatramana, K. Sivakumar, R.L. Gardas and K.D. Reddy, Thermochim. Acta, 581, 123 (2014);

https://doi.org/10.1016/j.tca.2014.01.027.

5. M. Gowrisankar, A. Venkatesulu, T.S. Krishna and K. Ravindhranath, J. Chem. Thermodyn., 107, 104 (2017); https://doi.org/10.1016/j.jct.2016.12.019.

6. A.I. Vogel, Text Book of Practical Organic Chemistry, Longman Green, London (1989).

7. P.V. Rao, M. Gowrisankar, L. Venkatramana, T.S. Krishna and K. Ravindhranath, J. Chem. Thermodyn., 101, 92 (2016); https://doi.org/10.1016/j.jct.2016.05.015.
8. M. Zábranský and V. Ruzicka Jr., J. Phys. Chem. Ref. Data, 33, 1071 (2004); https://doi.org/10.1063/1.1797811.

9. V. Pandiyan, S.L. Oswal, N.I. Malek and P. Vasantharani, Thermochim. Acta, 524, 140 (2011); https://doi.org/10.1016/i.tca.2011.07.005.

10. N.A. Lange, Handbook of Chemistry, McGraw Hill Handbook Publishers Inc., Sandusky, Ohio, edn 9 (1956).

11. S.C. Bhatia, R. Rani, J. Sangwan and R. Bhatia, Int. J. Thermophys., 32, 1163 (2011);

https://doi.org/10.1007/s10765-011-0995-x.

12. J. Jovanovic, A. Knezevic-Stevanovic and D. Grozdanic, J. Serb. Chem. Soc., 76, 417 (2011); https://doi.org/10.2298/JSC100511031J.

13. R. Shaw, J. Chem. Eng. Data, 14, 461 (1969); https://doi.org/10.1021/je60043a036.

14. D. Syamala, P. Venkateswarlu and K.S. Kumar, J. Chem. Eng. Data, 51, 928 (2006); https://doi.org/10.1021/je0504131.

15. G.C. Benson and O. Kiyohara, J. Chem. Thermodyn., 11, 1061 (1979); https://doi.org/10.1016/0021-9614(79)90136-8.

16. O. Redlich and A.T. Kister, Ind. Eng. Chem., 40, 345 (1948); https://doi.org/10.1021/ie50458a036.

17. B. Garcia, R. Alcalde, J.M. Leal and J.S. Matos, J. Chem. Soc., Faraday Trans., 92, 3347 (1996); https://doi.org/10.1039/FT9969203347.

18. A. Awasthi and A. Awasthi, Thermochim. Acta, 537, 57 (2012); https://doi.org/10.1016/j.tca.2012.03.001.

19. M.V. Rathnam, S. Mohite and M.S.S. Kumar, J. Solution Chem., 39, 1735 (2010); https://doi.org/10.1007/s10953-010-9610-1.

20. M.R. Islam and S.K. Quadri, Thermochim. Acta, 115, 335 (1987); https://doi.org/10.1016/0040-6031(87)88379-X.

21. G. Arul and L. Palaniappan and Indian J. Pure Appl. Phys., 43, 755 (2005).

22. R.A. Clará, A.C. Gómez Marigliano and H.N. Sólimo, J. Chem. Eng. Data, 51, 1473 (2006); https://doi.org/10.1021/je060150a.

23. H.T. Van and D. Patterson, J. Solution Chem., 11, 793 (1982); https://doi.org/10.1007/BF00650519.

24. D. Patterson and G. Delma, Discuss Faraday Soc., 49, 98 (1970); https://doi.org/10.1039/DF9704900098.

25. I. Prigogine, The Molecular Theory of Solution. North Holland Corp, Amsterdam (1957) 